\title{
Brain perfusion and permeability in patients with advanced, refractory glioblastoma treated with lomustine and the transforming growth factor- $\beta$ receptor I kinase inhibitor LY2157299 monohydrate
}

\author{
JUAN SEPULVEDA-SANCHEZ ${ }^{1}$, ANA RAMOS ${ }^{2}$, AMAYA HILARIO ${ }^{2}$, GUILLERMO DE VELASCO ${ }^{1}$, \\ DANIEL CASTELLANO ${ }^{1}$, MARTA GARCIA DE LA TORRE ${ }^{3}$, JORDI RODON ${ }^{4}$ and MICHAEL F. LAHN ${ }^{3}$ \\ Departments of ${ }^{1}$ Medical Oncology and ${ }^{2}$ Neuroradiology, University Hospital October 12, Madrid 28041, Spain; \\ ${ }^{3}$ Eli Lilly and Company, Indianapolis, IN 46285, USA; ${ }^{4}$ Department of Medical Oncology, \\ Vall d'Hebron University Hospital and The Autonomous University of Barcelona, Barcelona 08999, Spain
}

Received May 30, 2014; Accepted March 4, 2015

DOI: $10.3892 / 01.2015 .3106$

\begin{abstract}
Transforming growth factor- $\beta$ (TGF- $\beta$ ) signaling is associated with tumor progression and vascularization in malignant glioma. In the present study, magnetic resonance imaging was used to evaluate changes in the size and vascularity of glioblastomas in 12 patients who were treated with lomustine and the novel inhibitor of TGF- $\beta$ signaling, LY2157299 monohydrate. A response in tumor size was observed in 2 of the 12 patients; in 1 of these 2 patients, a reduction in vascular permeability and perfusion was also detected. The effect was observed following 4 cycles of treatment ( $\sim 3$ months). Changes in vascularity have not previously been attributed to treatment with lomustine; therefore, the effect may be associated with LY2157299 treatment. LY2157299 does not appear to have an anti-angiogenic effect when combined with lomustine, and hence may have a different mechanism of action profile compared with anti-angiogenic drugs.
\end{abstract}

\section{Introduction}

Identified in the early 1980 s, the transforming growth factor- $\beta$ (TGF- $\beta$ ) ligands, TGF- $\beta 1$, TGF- $\beta 2$ and TGF- $\beta 3$, regulate diverse biological functions $(1,2)$. These three ligands may bind to a specific receptor through their interaction with TGF- $\beta$ receptor I (TGF- $\beta$ RI), which subsequently heterodimerizes with the TGF- $\beta$ RII. This heterodimer complex phosphorylates the intracellular proteins SMAD2 and SMAD3, which initiate

Correspondence to: Dr Juan Sepulveda-Sanchez, Department of Medical Oncology, University Hospital October 12, Maternal and Child Building, Avenue Andalucía, Madrid 28041, Spain

E-mail: juanmanuel.sepulveda@salud.madrid.org

Key words: transforming growth factor- $\beta$ inhibitor LY2157299, combination therapy, magnetic resonance imaging, glioblastoma, lomustine an activation cascade to induce a number of nuclear transduction proteins. Through the induction of such proteins, the TGF- $\beta$ signaling pathway affects cellular proliferation, differentiation, motility, survival and apoptosis in tumor cells and the surrounding microenvironment. In glioblastoma, TGF- $\beta$ signaling is important in tumor progression $(3,4)$.

LY2157299 monohydrate (LY2157299) is a TGF- $\beta$ RI kinase inhibitor that interrupts the receptor-mediated signaling cascade (5-7). However, small-molecule TGF- $\beta$ inhibitors have been associated with unique cardiovascular toxicities in animals (8). Therefore, it is critical to develop a therapeutic window in which LY2157299 may be safely administered during a first-in-human dose (FHD) study. Based on preclinical information, a pharmacokinetic and pharmacodynamic model was developed to prospectively describe a therapeutic window to facilitate the safe clinical evaluation of LY2157299 (9). In short- and long-term toxicological studies in rats and dogs, LY2157299 was considered to potentially have the required therapeutic window in which a dose escalation to a biologically active dose range may safely be implemented (10).

Angiogenesis is critical in the development of glioma; anti-vascular endothelial growth factor agents, including bevacizumab, have shown activity in recurrent glioblastoma (11). TGF- $\beta$-mediated angiogenesis has also been described in mice, and postulated for humans. For example, mutations of components of the TGF- $\beta$ signaling pathway, such as Endoglin and SMAD4, have been associated with certain forms of hereditary hemorrhagic telangiectasia (12). The importance of the TGF- $\beta$ signaling pathway is further highlighted by the fact that the deletion of certain components, including TGF- $\beta 1$, TGF- $\beta$ RII, activin receptor-like kinase 1, Endoglin, SMAD1, SMAD4 and SMAD5, is not compatible with gestational survival. All these components are associated with embryonic lethality resulting from severe vascular abnormalities (13-16). In vitro studies indicate that the angiogenic effect of TGF- $\beta$ signaling is differentially modulated by endothelial migration and proliferation, and 
depends upon the different stages of angiogenic development. Overall, this appears to be dose- and cell-dependent (17).

Magnetic resonance imaging (MRI) of brain tumors may be utilized to assess anatomical changes in response to treatment, and is also able to detect changes in vascular permeability, blood volume, blood flow and mean transit time of blood flow (17). Measures of relative cerebral blood volume (rCBV) and permeability have been used as antitumor response markers following the initiation of anti-angiogenic treatment $(18,19)$. For example, patients who were treated with cediranib and who exhibited increased perfusion also experienced prolonged survival (20). rCBV has also been demonstrated to be sensitive to tumor grade, to be predictive of survival and to be able to distinguish contrast enhancement following post-radiation changes (21-26). These observations indicate that MRI techniques facilitate the assessment of the anti-vascular activity of novel antitumor agents. In the present study, the perfusion and permeability of glioblastoma was assessed in patients who received combination lomustine and LY2157299 therapy, in order to determine whether this treatment exerts anti-angiogenic effects.

\section{Patients and methods}

Patients. Patients with relapsed and progressive glioblastoma were eligible to participate in the FHD study, as described previously (27). All patients were required to have an Eastern Cooperative Oncology Group performance status score of $\leq 2$, adequate hematological, hepatic and renal function, and must have discontinued all previous cancer therapies $>4$ weeks prior to study enrollment. The exclusion criteria included medically uncontrolled cardiovascular illness and electrocardiogram anomalies.

All patients provided written informed consent to participate in the study, and the protocol was approved by the ethics committees of University Hospital 12 October (Madrid, Spain) and Vall d'Hebron University Hospital (Barcelona, Spain). The study was conducted in accordance with good clinical practice and the ethics principles of the Declaration of Helsinki.

Study design. The MRI-based assessment was conducted as part of a main protocol evaluating the safety and pharmacokinetics of LY2157299 (Eli Lilly and Company, Indianapolis, IN, USA), either alone or in combination with lomustine (Medac GmbH, Wedel, Germany) (27,28). LY2157299 was evaluated in a multicenter, open-label, non-randomized, dose-escalation FHD phase I study. Patients participating in this substudy received two doses of LY2157299 (160 and $300 \mathrm{mg} /$ day), in combination with lomustine at standard doses: $100 \mathrm{mg} / \mathrm{m}^{2}$ every 6 weeks in the first cycle, and $130 \mathrm{mg} / \mathrm{m}^{2}$ in the second and subsequent cycles, according to the patient's tolerance.

Safety analysis. Safety assessment was based on the summaries of adverse events, including severity [as defined by the Common Terminology Criteria for Adverse Events (version 3.0)] (29), and possible associations with the study drug, dose-limiting toxicities and laboratory changes at each dose level. Logistic regression analysis for the probability of experiencing a dose-limiting toxicity was not performed, as there was only one occurrence of a dose-limiting toxicity. Safety was also analyzed by evaluation of Eastern Cooperative Oncology Group performance status (30), electrocardiogram and echocardiography/Doppler scanning. Standard laboratory tests, including chemistry, hematology and urinalysis panels, were also conducted. All concomitant medications were documented throughout the patient's participation in the study.

Treatment. LY2157299 was administered orally in tablet form at 80- and 150-mg doses twice daily (in the morning and evening; total, 160 and $300 \mathrm{mg} /$ day) for 14 days, followed by a 14-day drug-free period, for a 28 -day cycle. Lomustine was administered at a starting dose of $100 \mathrm{mg} / \mathrm{m}^{2}$ in the first cycle and $130 \mathrm{mg} / \mathrm{m}^{2}$ in the second and subsequent cycles; the time between lomustine doses was 6 weeks. Based on toxicities, doses were lowered when indicated.

Radiological assessment. All patients underwent a baseline MRI exam $<2$ weeks prior to the commencement of treatment, and a second MRI exam prior to the third cycle of treatment. Radiographic changes were evaluated according to Macdonald criteria (31).

Conventional MRI. Imaging was performed with a $1.5 \mathrm{~T}$ scanner (Signa Excite; GE Healthcare, Milwaukee, WI, USA). Anatomic sequences were conducted as follows: A 3-plane localizer sequence, sagittal T1-weighted with an inversion recovery (IR) pulse [repetition time (TR), 2,400 msec; echo time (TE), $24 \mathrm{msec}$; IR, $750 \mathrm{msec}$, axial T2-weighted fast spin-echo (TR, 4,100 msec, TE, $85 \mathrm{msec}$ ), and fluid-attenuated IR [FLAIR; TR, 8,000 msec; TE, $120 \mathrm{msec}$; inversion time (TI), 2,000 msec]. Post-contrast axial and coronal T1-weighted images with an IR pulse (TR, 2,400 msec; TE, $24 \mathrm{msec}$; IR, $750 \mathrm{msec}$ ) were obtained following the acquisition of the perfusion MRI data. All data were obtained using 4-mm thick sections with a 1-mm skip, a 320x256 matrix and a field of view (FOV) of $24 \times 24 \mathrm{~cm}$.

Dynamic contrast-enhanced perfusion MRI. Dynamic contrast-enhanced T2-weighted gradient-echo echo-planar images were acquired during the first pass of a bolus of gadobutrol (Gadavist ${ }^{\mathrm{TM}}, 1 \mathrm{mmol} / \mathrm{ml}$; Berlex Laboratories, Wayne, NJ, USA) at a dose of $0.1 \mathrm{mmol} / \mathrm{kg}$. For perfusion MRI, 19 sections were selected to cover the tumor on the basis of T2-weighted and FLAIR images. Imaging parameters were as follows: TR/TE, 2,000/21.1 msec; FOV, 26x26 cm; section thickness, $4 \mathrm{~mm}$ with a $0.4-\mathrm{mm}$ skip, a matrix of $128 \times 128$ and a flip angle of $90^{\circ}$. A series of 40 multisection acquisitions was acquired at $0.2-\mathrm{sec}$ intervals. The first 8 acquisitions were performed prior to the injection of the contrast agent in order to establish a precontrast baseline. For the ninth acquisition, gadobutrol was injected at a rate of $5 \mathrm{ml} / \mathrm{sec}$ using a power injector (Medrad ${ }^{\circledR}$ Spectris Solaris ${ }^{\circledR}$ EP MR Injection System; Medrad Inc., Bayer Healthcare, Indianola, PA, USA) followed by the administration of a $20-\mathrm{ml}$ bolus of saline at $5 \mathrm{ml} / \mathrm{sec}$. Immediately prior to dynamic imaging, a prebolus dose $(2 \mathrm{ml})$ of gadobutrol was administered to diminish any $\mathrm{T} 1$ effects that may have resulted from agent extravasation.

Perfusion MRI data evaluation. Dynamic susceptibility contrast images were processed on an Advantage Workstation 
Table I. Patient demographics and disease characteristics of all enrolled and treated patients by dose.

\begin{tabular}{|c|c|c|c|c|c|c|}
\hline $\begin{array}{l}\text { Patient } \\
\text { ID }\end{array}$ & Gender & $\begin{array}{l}\text { Age, } \\
\text { years }\end{array}$ & $\begin{array}{l}\text { Original/ } \\
\text { subsequent } \\
\text { diagnosis }\end{array}$ & $\begin{array}{l}\text { Time from } \\
\text { initial } \\
\text { diagnosis to } \\
\text { study entry }\end{array}$ & $\begin{array}{l}\text { Primary/ } \\
\text { secondary } \\
\text { GBM }\end{array}$ & Previous treatments \\
\hline S1 & M & 45 & GBM & $\begin{array}{l}3 \text { years, } \\
5 \text { months }\end{array}$ & Primary & $\begin{array}{l}\text { Chemoradiotherapy with TMZ, } \\
\text { adjuvant TMZ ( } 6 \text { cycles), } \\
\text { surgery (complete resection) and } \\
\text { bevacizumab + irinotecan ( } 12 \text { cycles) }\end{array}$ \\
\hline $\mathrm{S} 2$ & M & 57 & GBM & $\begin{array}{l}1 \text { year, } \\
4 \text { months }\end{array}$ & Primary & $\begin{array}{l}\text { Chemoradiotherapy with TMZ, } \\
\text { adjuvant TMZ ( } 5 \text { cycles), } \\
\text { surgery (complete resection) and } \\
\text { bevacizumab + irinotecan ( } 12 \text { cycles) }\end{array}$ \\
\hline $\mathrm{S} 3$ & $\mathrm{~F}$ & 57 & GBM & $\begin{array}{l}1 \text { year, } \\
9 \text { months }\end{array}$ & Primary & $\begin{array}{l}\text { Chemoradiotherapy with TMZ } \\
\text { (no adjuvant TMZ due to } \\
\text { thrombocytopenia) and } \\
\text { bevacizumab + irinotecan ( } 24 \text { cycles) }\end{array}$ \\
\hline $\mathrm{S} 4$ & M & 42 & GBM & $\begin{array}{l}1 \text { year, } \\
4 \text { months }\end{array}$ & Primary & $\begin{array}{l}\text { Chemoradiotherapy with TMZ, } \\
\text { adjuvant TMZ ( } 2 \text { cycles) and } \\
\text { bevacizumab + irinotecan ( } 20 \text { cycles })\end{array}$ \\
\hline S5 & M & 44 & GBM & $\begin{array}{l}2 \text { years, } \\
2 \text { months }\end{array}$ & Primary & $\begin{array}{l}\text { Chemoradiotherapy with TMZ, } \\
\text { adjuvant TMZ ( } 6 \text { cycles), } \\
\text { second chemoradiotherapy and } \\
\text { bevacizumab + irinotecan ( } 2 \text { cycles) }\end{array}$ \\
\hline S6 & M & 31 & GBM & 1 year & Primary & $\begin{array}{l}\text { Chemoradiotherapy with TMZ and } \\
\text { bevacizumab + irinotecan ( } 14 \text { cycles) }\end{array}$ \\
\hline S7 & M & 51 & GBM & $\begin{array}{l}1 \text { year, } \\
2 \text { months }\end{array}$ & Primary & $\begin{array}{l}\text { Chemoradiotherapy with TMZ, } \\
\text { adjuvant TMZ ( } 2 \text { cycles) and } \\
\text { bevacizumab + irinotecan ( } 12 \text { cycles) }\end{array}$ \\
\hline S8 & $\mathrm{F}$ & 35 & $\begin{array}{l}\text { Oligodendroglioma/ } \\
\text { anaplastic } \\
\text { oligodendroglioma }\end{array}$ & $\begin{array}{l}6 \text { years, } \\
4 \text { months }\end{array}$ & $\begin{array}{l}\text { Not } \\
\text { applicable }\end{array}$ & $\begin{array}{l}\text { Radiotherapy, } \\
\text { adjuvant TMZ ( } 18 \text { cycles), } \\
\text { second surgery at progression with } \\
\text { partial resection and } \\
\text { adjuvant TMZ ( } 8 \text { cycles) }\end{array}$ \\
\hline S9 & M & 55 & GBM & 7 months & Primary & $\begin{array}{l}\text { Chemoradiotherapy with TMZ, } \\
\text { adjuvant TMZ ( } 6 \text { cycles }) \text { and } \\
\text { dose intense TMZ + bevacizumab } \\
\text { ( } 5 \text { months })\end{array}$ \\
\hline S10 & M & 30 & $\begin{array}{l}\text { Anaplastic } \\
\text { astrocytoma/ } \\
\text { GBM }\end{array}$ & $\begin{array}{l}5 \text { years, } \\
6 \text { months }\end{array}$ & $\begin{array}{l}\text { Not } \\
\text { applicable }\end{array}$ & $\begin{array}{l}\text { Chemoradiotherapy with TMZ, } \\
\text { adjuvant TMZ ( } 1 \text { cycle), } \\
\text { dose intense TMZ ( } 4 \text { years) and } \\
\text { surgery (at relapse) }\end{array}$ \\
\hline $\mathrm{S} 11$ & M & 59 & GBM & 11 months & Primary & $\begin{array}{l}\text { Chemoradiotherapy with TMZ, } \\
\text { adjuvant TMZ ( } 4 \text { cycles) and } \\
\text { second surgery (at relapse) }\end{array}$ \\
\hline $\mathrm{S} 12$ & M & 58 & GBM & $\begin{array}{l}1 \text { year, } \\
5 \text { months }\end{array}$ & Primary & $\begin{array}{l}\text { Chemoradiotherapy with TMZ, } \\
\text { adjuvant TMZ ( } 11 \text { cycles) and } \\
\text { surgery (partial resection) }\end{array}$ \\
\hline
\end{tabular}

GBM, glioblastoma; M, male; F, female; TMZ, temozolomide.

using FuncTool (GE Healthcare). The beginning and the end of the first-pass bolus were determined through inspection of the time-signal-intensity curve and care was taken to exclude any recirculation-related signal intensity. Cerebral blood volume $(\mathrm{CBV})$ refers to the amount of blood in a given region of brain tissue at any time, commonly measured in milliliters per $100 \mathrm{~g}$ of brain tissue. As the CBV must be expressed relative to an internal reference, it was normalized in the present study by expressing ratios relative to values measured in the normal white matter of the contralateral lobe; these values 
Table II. Overview of the rCBV and perfusion changes in glioblastoma patients.

\begin{tabular}{|c|c|c|c|c|c|c|c|c|c|c|c|c|c|}
\hline \multirow{2}{*}{$\begin{array}{l}\text { Patient } \\
\text { ID }\end{array}$} & \multicolumn{2}{|c|}{ Baseline } & \multicolumn{2}{|c|}{$\begin{array}{c}\text { After } \\
2 \text { cycles }\end{array}$} & \multicolumn{2}{|c|}{$\begin{array}{c}\text { After } \\
4 \text { cycles }\end{array}$} & \multicolumn{2}{|c|}{$\begin{array}{c}\text { After } \\
6 \text { cycles }\end{array}$} & \multicolumn{2}{|c|}{$\begin{array}{c}\text { After } \\
8 \text { cycles }\end{array}$} & \multicolumn{2}{|c|}{$\begin{array}{c}\text { After } \\
10 \text { cycles }\end{array}$} & \multirow{2}{*}{$\begin{array}{c}\text { Best } \\
\text { response }\end{array}$} \\
\hline & $\mathrm{rCBV}$ & Perf & $\mathrm{rCBV}$ & Perf & $\mathrm{rCBV}$ & Perf & $\mathrm{rCBV}$ & Perf & $\mathrm{rCBV}$ & Perf & $\mathrm{rCBV}$ & Perf & \\
\hline S1 & 7.60 & 0.80 & 9.45 & 4.72 & - & - & - & - & - & - & - & - & PD \\
\hline $\mathrm{S} 2$ & 8.37 & 2.80 & 9.79 & 1.80 & - & - & - & - & - & - & - & - & PD \\
\hline S3 & 2.70 & 1.30 & n.a. & n.a. & - & - & - & - & - & - & - & - & PD \\
\hline S4 & 2.36 & 4.00 & n.a. & n.a. & - & - & - & - & - & - & - & - & PD \\
\hline S5 & 1.96 & 1.50 & n.a. & n.a. & - & - & - & - & - & - & - & - & PD \\
\hline S6 & 4.70 & 1.00 & 9.76 & -0.40 & - & - & - & - & - & - & - & - & PD \\
\hline S7 & 1.12 & 0.40 & 2.74 & 3.10 & - & - & - & - & - & - & - & - & PD \\
\hline S8 & 3.28 & 5.00 & 2.22 & 4.70 & 2.02 & 7.20 & 1.55 & 4.70 & 1.17 & 2.80 & 5.10 & 4.00 & PR \\
\hline S9 & 8.00 & 3.60 & 12.00 & 4.10 & - & - & - & - & - & - & - & - & PD \\
\hline S10 & 1.20 & n.a. & 1.20 & 0.50 & 1.20 & 1.40 & 1.20 & 1.40 & 1.10 & 1.30 & 1.10 & 2.00 & PR \\
\hline S11 & 2.50 & n.a. & 4.30 & n.a. & 4.30 & n.a. & - & - & - & - & - & - & PD \\
\hline S12 & 4.70 & 10.00 & 8.20 & 6.20 & 8.20 & 7.40 & - & - & - & - & - & - & PD \\
\hline
\end{tabular}

rCBV, relative cerebral blood volume; Perf, perfusion; PD, progressive disease; PR, partial response; n.a., not available; -, data not collected due to progression.

Table III. Description of rCBV prior to treatment and following two cycles of LY2157299.

\begin{tabular}{|c|c|c|c|c|c|c|c|c|}
\hline \multirow[b]{3}{*}{ Time-point } & \multirow[b]{3}{*}{$\mathrm{n}$} & \multicolumn{7}{|c|}{$\mathrm{rCBV}$} \\
\hline & & \multirow[b]{2}{*}{ Mean $^{\mathrm{a}}$} & \multirow[b]{2}{*}{ SD } & \multirow[b]{2}{*}{ Min } & \multirow[b]{2}{*}{ Max } & \multicolumn{3}{|c|}{ Percentiles } \\
\hline & & & & & & 25 & 50 & 75 \\
\hline Baseline & 12 & 4.02 & 2.66 & 1.12 & 8.37 & 2.06 & 2.99 & 6.8750 \\
\hline After 2 cycles & 9 & 6.63 & 4.01 & 1.20 & 12.00 & 2.48 & 8.20 & 9.7750 \\
\hline
\end{tabular}

${ }^{\mathrm{a}} \mathrm{P}=0.015$. $\mathrm{rCBV}$, relative cerebral blood volume; $\mathrm{SD}$, standard deviation.

were referred to as rCBV. Color-coded rCBV maps were generated to target regions of maximum abnormality. Two neuroradiologists determined 3 regions of interest (ROIs) within the tumor, on areas exhibiting the highest intratumoral rCBV on the color-coded maps. The standardized ROI was 2-3 $\mathrm{mm}^{2}$ and was used for the majority of the tumor and white matter measurements. Care was taken to avoid the inclusion of large intra- or peritumoral vessels, as these may confound perfusion measurements. The maximum $\mathrm{rCBV}$ value in the intratumoral ROIs was selected for quantitative analysis, and correlated with the corresponding specimen histopathology. This method has been demonstrated to provide the most optimal interobserver and intraobserver reproducibility (13).

Statistics. A two-tailed Wilcoxon test for paired samples was used to establish the significance of any differences in the same variable, in perfusion and $\mathrm{rCBV}$ observed between different time points, and between baseline MRI and MRI performed after the completion of two cycles of chemotherapy. Summary statistics were reported as the median and standard deviations. A two-sided P-value of $<0.05$ was considered to indicate a statistically significant difference.
SPSS software version 12 (SPSS, Inc., Chicago, IL, USA) was used for the statistical analyses.

\section{Results}

Patient demographics and disease characteristics. In this single-institution imaging study, patients were enrolled between September 2010 and June 2011. All patients participated in the FHD study of LY2157299 combined with lomustine, and discontinued all previous therapies for glioblastoma, such as radiochemotherapy with temozolamide or other investigational therapy regarded to be effective in glioblastoma, prior to the commencement of the study. Of the 12 patients enrolled, 8 had been treated with bevacizumab-based therapies (Table I). Two patients (S11 and S12) did not receive additional chemotherapies following their first relapse, but instead underwent re-resection. Two patients were considered to have secondary glioblastoma based on their previous low-grade glioma diagnosis (S8 and S10).

Analysis of changes in $r C B V$ and perfusion. The details of the effects of the treatment on $\mathrm{rCBV}$ and perfusion are listed 
Table IV. Description of perfusion prior to treatment and following two cycles of LY2157299 and lomustine.

\begin{tabular}{|c|c|c|c|c|c|c|c|c|}
\hline \multirow[b]{3}{*}{ Time-point } & \multirow[b]{3}{*}{$\mathrm{n}$} & \multicolumn{7}{|c|}{ Perfusion } \\
\hline & & \multirow[b]{2}{*}{ Mean ${ }^{\mathrm{a}}$} & \multirow[b]{2}{*}{ SD } & \multirow[b]{2}{*}{ Min } & \multirow[b]{2}{*}{ Max } & \multicolumn{3}{|c|}{ Percentiles } \\
\hline & & & & & & 25 & 50 & 75 \\
\hline Baseline & 10 & 3.04 & 2.88 & 0.40 & 10.00 & 0.95 & 2.15 & 4.25 \\
\hline After 2 cycles & 8 & 3.07 & 2.27 & 0.40 & 6.20 & 0.82 & 3.60 & 4.67 \\
\hline
\end{tabular}

${ }^{\mathrm{a}} \mathrm{P}=0.93$. $\mathrm{rCBV}$, relative cerebral blood volume; $\mathrm{SD}$, standard deviation.
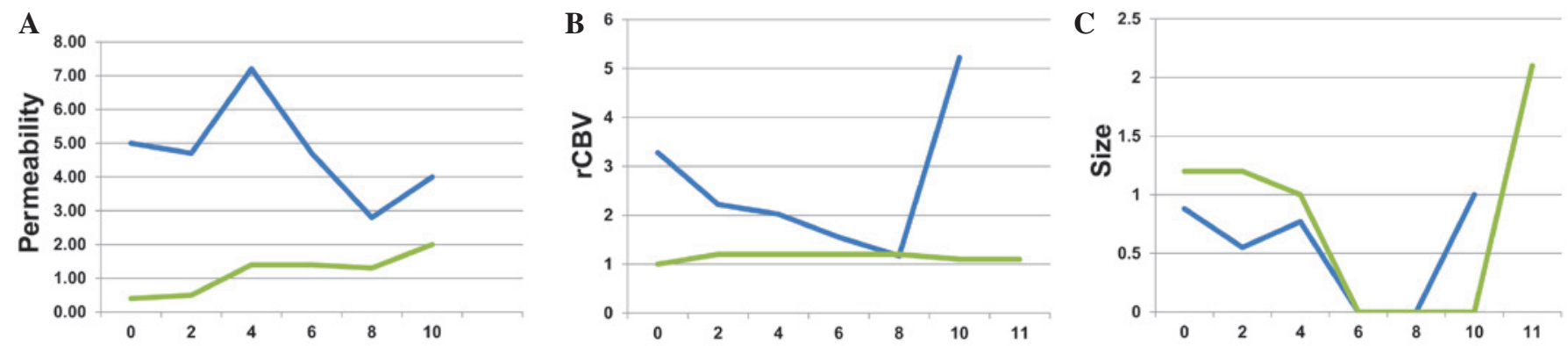

Figure 1. Comparison of magnetic resonance imaging-evaluated responses in patients S8 (blue line) and S10 (green line). (A) Permeability and (B) relative cerebral blood volume ( $(\mathrm{CBV})$ were reduced in patient $\mathrm{S} 8$, while patient $\mathrm{S} 10$ showed no change in $\mathrm{rCBV}$ and an increase in permeability. (C) Both patients showed a response in the size of the tumors, starting at cycle 4 . The product sum of the perpendicular diameters (y-axis) was reduced around cycle 6 (x-axis representing cycles of treatment).

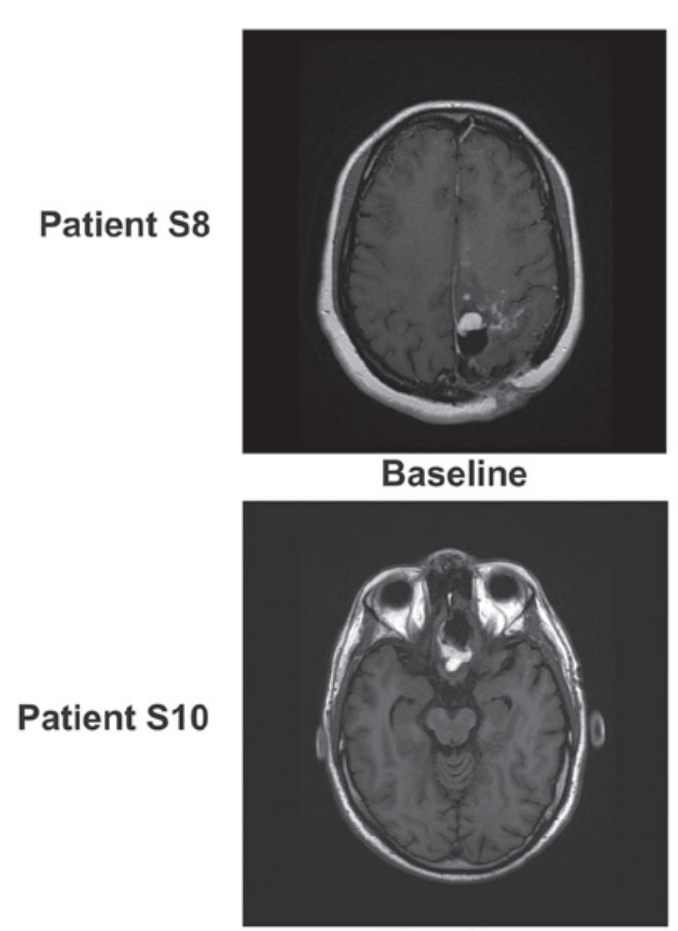

Baseline

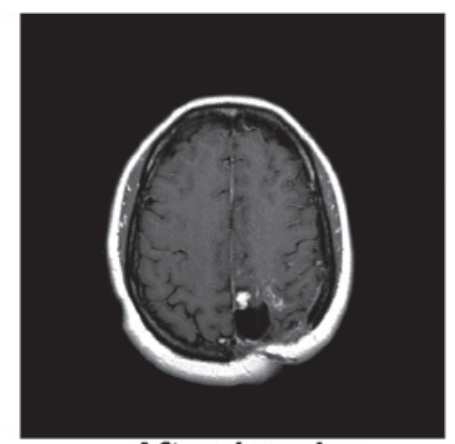

After 4 cycles

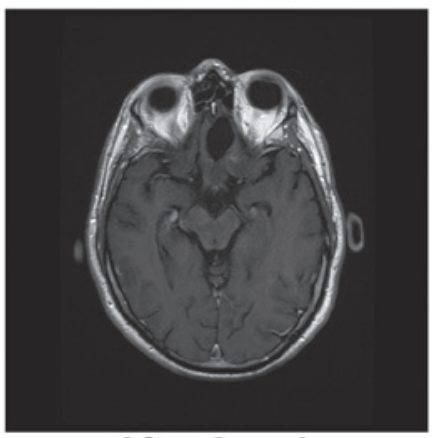

After 6 cycles

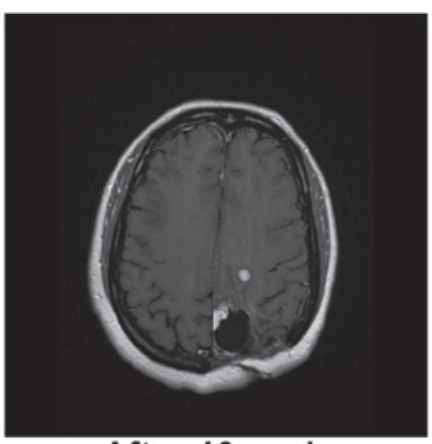

After 10 cycles

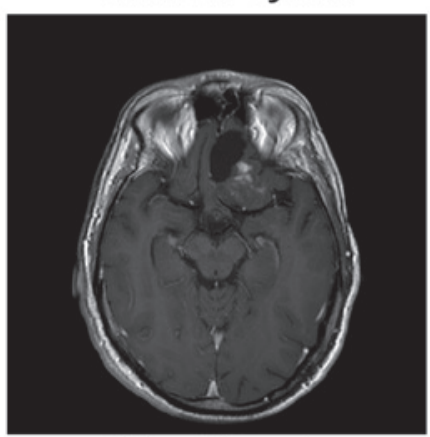

After 11 cycles

Figure 2. Images of magnetic resonance imaging-evaluated responses for patients S8 and S10. The two patients exhibited a partial response after several cycles of treatment with LY2157299, with reappearance of the lesion after $\sim 10$ cycles.

in Table II. rCBV increased significantly during treatment (Table III): The baseline mean and median values were 4.02 and 2.99, respectively. Following the second cycle of LY2157299 + lomustine, the mean and median values were 6.63 and 8.20, respectively (Wilcoxon test, $\mathrm{P}=0.015$ ). Changes in the mean and median rCBV reflect the tumor progression in the majority of cases without appreciable normalization of the tumor vessels, as observed with anti-angiogenic agents.

The mean and median perfusion values showed a marginal, non-significant increase during treatment (Table IV): The 
baseline values were 3.04 and 2.15, respectively, and following two cycles of LY2157299 + lomustine, the mean and median perfusion values were 3.07 and 3.60, respectively (Wilcoxon test, $\mathrm{P}=0.93$ ). Although the majority of the patients exhibited an increase in rCBV and permeability, 1 patient displayed reduced permeability and $\mathrm{rCBV}$ following the tumor response (Fig. 1A and B).

Efficacy measures. According to Macdonald criteria, 2 patients (S8 and S10) responded to combined treatment. Responses were noted after 4 cycles (Fig. 1C). Fig. 2 shows that the response was observed at cycle 4 in patient $S 8$, but at cycle 6 in patient S10.

\section{Discussion}

The present study assessed whether LY2157299 has antitumor effects, as detected by perfusion MRI. The results indicated that LY2157299 in combination with lomustine does not reduce $\mathrm{rCBV}$ and permeability, as previously described for anti-angiogenic drugs such as bevacizumab or cediranib (32). A number of anti-angiogenic agents have been investigated for their potential ability to treat glioblastoma, and various imaging techniques, such as perfusion MRI and dynamic susceptibility weighted MRI, have been proposed to measure responses to treatment (33). Whilst lomustine monotherapy has not specifically been evaluated as an anti-angiogenic agent, a recent study observed its anti-angiogenic effect as part of a combination therapy of procarbazine, lomustine and vincristine (34). In this study, patients had undergone fewer prior treatments compared with the present study. The shorter median treatment of $<1$ cycle observed in the current study, compared with that of other trials, is a consequence of the highly pre-treated study population used for this study.

In the present study, evidence of responses began to emerge after the patients received 4 cycles of treatment, and became more clear following 6 cycles. This pattern of responses is inconsistent with that of previous studies reporting tumor shrinkage with chemotherapy, in which responses were generally observed within the first month of treatment (35). A recent phase III study confirmed that the early responses with lomustine are commonly visible within the first month of treatment (36). Due to this lack of early antitumor responses, it is possible that the changes in the present study are predominantly a result of the LY2157299 treatment. As demonstrated previously (27), LY2157299 monotherapy in patients with glioblastoma shows preliminary stabilization of the tumor growth, followed by a tumor response several months later. In contrast to the previous studies, the present study shows that these responses may also be associated with changes in the vasculature of the glioma.

In the present study, 2 patients with relapsed glioblastoma responded to LY2157299 and lomustine treatment; one of these patients also had measurable reduction in $\mathrm{rCBV}$ and permeability. Although there was no control in this study, the late responses in the 2 patients may be attributable to LY2157299 and not to lomustine, which is predicted to produce early antitumor effects. This is the first study evaluating the impact of a TGF- $\beta$ inhibitor on vascular changes in patients with glioma.

\section{Acknowledgements}

This study was sponsored by Eli Lilly and Company (Indianapolis, IN, USA). Dr Michael F. Lahn and Dr Marta Garcia de la Torre are employees of Eli Lilly and Company.

\section{References}

1. Massagué J, Blain SW and Lo RS: TGFbeta signaling in growth control, cancer, and heritable disorders. Cell 103: 295-309, 2000.

2. Hughes C, Bauer E and Roberts AP: Spread of R-plasmids among Escherichia coli causing urinary tract infections. Antimicrob Agents Chemother 20: 496-502, 1981.

3. Bruna A, Darken RS, Rojo F, et al: High TGFbeta-Smad activity confers poor prognosis in glioma patients and promotes cell proliferation depending on the methylation of the PDGF-B gene. Cancer Cell 11: 147-160, 2007.

4. Peñuelas S, Anido J,Prieto-Sánchez RM, et al: TGF-beta increases glioma-initiating cell self-renewal through the induction of LIF in human glioblastoma. Cancer Cell 15: 315-327, 2009.

5. Sawyer JS,BeightDW,BrittKS, et al: Synthesis and activity of new aryl- and heteroaryl-substituted 5,6-dihydro-4H-pyrrolo[1,2-b] pyrazole inhibitors of the transforming growth factor-beta type I receptor kinase domain. Bioorg Med Chem Lett 14: 3581-3584, 2004.

6. Anido J, Sáez-Borderías A, Gonzàlez-Juncà A, et al: TGF- $\beta$ Receptor Inhibitors Target the CD44(high)/Id1(high) Glioma-Initiating Cell Population in Human Glioblastoma. Cancer Cell 18: 655-668, 2010.

7. Li HY, Wang Y, Yan L, et al: Novel and potent transforming growth factor beta type I receptor kinase domain inhibitor: 7-amino 4-(2-pyridin-2-yl-5,6-dihydro-4H-pyrrolo[1,2-b] pyrazol-3-yl)-quinolines. Bioorg Med Chem Lett 14: 3585-3588, 2004.

8. Anderton MJ, Mellor HR, Bell A, et al: Induction of heart valve lesions by small-molecule ALK5 inhibitors. Toxicol Pathol 39: 916-924, 2011.

9. Bueno L, de Alwis DP, Pitou C, et al: Semi-mechanistic modelling of the tumour growth inhibitory effects of LY2157299, a new type I receptor TGF-beta kinase antagonist, in mice. Eur J Cancer 44: 142-150, 2008.

10. Gueorguieva I, Cleverly AL, Stauber A, et al: Defining a therapeutic window for the novel TGF- $\beta$ inhibitor LY2157299 monohydrate based on a pharmacokinetic/pharmacodynamic model. Br J Clin Pharmacol 77: 796-807, 2014.

11. Vredenburgh JJ, Desjardins A, Herndon JE II, et al: Phase II trial of bevacizumab and irinotecan in recurrent malignant glioma. Clin Cancer Res 13: 1253-1259, 2007.

12. Lenato GM and Guanti G: Hereditary Haemorrhagic Telangiectasia (HHT): Genetic and molecular aspects. Curr Pharm Des 12: 1173-1193, 2006.

13. Lechleider RJ, Ryan JL, Garrett L, et al: Targeted mutagenesis of Smad1 reveals an essential role in chorioallantoic fusion. Dev Biol 240: 157-167, 2001.

14. Li F, Lan Y, Wang Y, et al: Endothelial Smad4 maintains cerebrovascular integrity by activating $\mathrm{N}$-cadherin through cooperation with Notch. Dev Cell 20: 291-302, 2011

15. Dickinson ME, Selleck MA, McMahon AP and Bronner-Fraser M: Dorsalization of the neural tube by the non-neural ectoderm. Development 121: 2099-2106, 1995.

16. Oshima M, Oshima $\mathrm{H}$ and Taketo MM: TGF-beta receptor type II deficiency results in defects of yolk sac hematopoiesis and vasculogenesis. Dev Biol 179: 297-302, 1996.

17. Goumans MJ, Valdimarsdottir G, Itoh S, et al: Balancing the activation state of the endothelium via two distinct TGF-beta type I receptors. EMBO J 21: 1743-1753, 2002.

18. Gerstner ER, Sorensen AG, Jain RK and Batchelor TT: Advances in neuroimaging techniques for the evaluation of tumor growth, vascular permeability, and angiogenesis in gliomas. Curr Opin Neurol 21: 728-735, 2008.

19. Pechman KR, Donohoe DL, Bedekar DP, et al: Evaluation of combined bevacizumab plus irinotecan therapy in brain tumors using magnetic resonance imaging measures of relative cerebral blood volume. Magn Reson Med 68: 1266-1272, 2012.

20. Sorensen AG, Emblem KE, Polaskova P, et al: Increased survival of glioblastoma patients who respond to antiangiogenic therapy with elevated blood perfusion. Cancer Res 72: 402-407, 2012. 
21. Hilario A, Ramos A, Perez-Nuñez A, et al: The added value of apparent diffusion coefficient to cerebral blood volume in the preoperative grading of diffuse gliomas. AJNR Am J Neuroradiol 33: 701-707, 2012.

22. Maeda M, Itoh S, Kimura $\mathrm{H}$, et al: Tumor vascularity in the brain: Evaluation with dynamic susceptibility-contrast MR imaging. Radiology 189: 233-238, 1993.

23. Aronen HJ, Gazit IE, Louis DN, et al: Cerebral blood volume maps of gliomas: Comparison with tumor grade and histologic findings. Radiology 191: 41-51, 1994.

24. Donahue KM, Krouwer HG, Rand SD, et al: Utility of simultaneously acquired gradient-echo and spin-echo cerebral blood volume and morphology maps in brain tumor patients. Magn Reson Med 43: 845-853, 2000.

25. Law M, Oh S, Babb JS, et al: Low-grade gliomas: Dynamic susceptibility-weighted contrast-enhanced perfusion MR imaging - prediction of patient clinical response. Radiology 238 658-667, 2006

26. Sugahara T, Korogi Y, Tomiguchi S, et al: Posttherapeutic intraaxial brain tumor: The value of perfusion-sensitive contrast-enhanced MR imaging for differentiating tumor recurrence from nonneoplastic contrast-enhancing tissue. AJNR Am J Neuroradiol 21: 901-909, 2000.

27. Rodon Ahnert J, Baselga J, Calvo E, et al: First human dose (FHD) study of the oral transforming growth factor-beta receptor I kinase inhibitor LY2157299 in patients with treatment-refractory malignant glioma. J Clin Oncol 29: abstract 3011, 2011.

28. Azaro A, Baselga J, Sepúlveda JM, et al: The oral transforming growth factor-beta (TGF- $\beta$ ) receptor I kinase inhibitor LY2157299 plus lomustine in patients with treatment-refractory malignant glioma: The first human dose study. J Clin Oncol 30: abstract 2042, 2012.
29. Trotti A, Colevas AD, Setser A, et al: CTCAE v3.0: development of a comprenhensive grading system for the adverse effects of cancer treatment. Semin Radiat Oncol 13: 176-181, 2003.

30. Oken MM, Creech RH, Tormey DC, et al: Toxicity and response criteria of the Eastern Cooperative Oncology Group. Am J Clin Oncol 5: 649-655, 1982.

31. Macdonald DR, Cascino TL, Schold SC Jr and Cairncross JG: Response criteria for phase II studies of supratentorial malignant glioma. J Clin Oncol 8: 1277-1280, 1990.

32. Vidiri A, Pace A, Fabi A, et al: Early perfusion changes in patients with recurrent high-grade brain tumor treated with Bevacizumab: Preliminary results by a quantitative evaluation. J Exp Clin Cancer Res 31: 33, 2012.

33. Thompson G, Mills SJ, Coope DJ, et al: Imaging biomarkers of angiogenesis and the microvascular environment in cerebral tumours. Br J Radiol 84: S127-S144, 2011.

34. Jenkinson MD, Smith TS, Joyce KA, et al: Cerebral blood volume, genotype and chemosensitivity in oligodendroglial tumours. Neuroradiology 48: 703-713, 2006.

35. Kappelle AC, Postma TJ, Taphoorn MJ, et al: PCV chemotherapy for recurrent glioblastoma multiforme. Neurology 56: 118-120, 2001.

36. Wick W, Puduvalli VK, Chamberlain MC, et al: Phase III study of enzastaurin compared with lomustine in the treatment of recurrent intracranial glioblastoma. J Clin Oncol 28: 1168-1174, 2010. 